\title{
Dietary intakes and adipose tissue levels of linoleic acid in peptic ulcer disease
}

\author{
BY J. KEARNEY, N. P. KENNEDY, P. W. N. KEELING, J. J. KEATING, \\ LOUISE GRUBB, MARGARET KENNEDY AND M. J. GIBNEY* \\ Division of Nutritional Sciences, Department of Clinical Medicine, Trinity College Medical School, \\ St James's Hospital, Dublin 8, Republic of Ireland
}

(Received 28 February 1989 - Accepted 20 July 1989)

\begin{abstract}
Adipose tissue levels of linoleic acid were determined from biopsies of subcutaneous abdominal fat of normal healthy controls $(n 40)$ and from two patient groups with endoscopically evaluated non-ulcer dyspepsia $(n 40)$ or peptic ulcer disease $(n$ 38). The level $(\mathrm{g} / 100 \mathrm{~g})$ of adipose tissue linoleic acid in the normal healthy controls $(15.0$ (SD $4 \cdot 1))$ was significantly $(P<0.05)$ greater than that in patients with non-ulcer dyspepsia (12.8 (SD 3.5)) and in patients with peptic ulcer disease (11.7 (SD 2.7)). A dietary history revealed a lower intake of linoleic acid and a significantly $(P<0.05)$ lower intake of dietary fibre (g/d) for both the non-ulcer dyspepsia (15.9 (SD 6.2)) and peptic ulcer disease (15.2 (SD 7.8)) patients compared with normal healthy controls (20.2 (SD 11.2)). Adipose tissue linoleic acid tended to increase with indices of increasing socioeconomic status, although the differences between patient and controls were not confounded by socioeconomic status. Patients with dyspepsia reported more foods causing symptoms (onion, fried foods, alcohol, citrus fruits and spices) and more foods giving relief (milk, bread) compared with control orthopaedic patients.
\end{abstract}

Linoleic acid: Adipose tissue: Peptic ulcer

There is at present an increased interest in the potential role of essential fatty acids in peptic ulcer disease. The administration of arachidonic acid and linoleic acid to rats reduces the extent of ethanol- or indomethacin-induced gastric lesions (Hollander et al. 1982; Tarnawski et al. 1985; Huang et al. 1987). Epidemiological evidence for a link between the declining incidence of peptic ulcer disease in the USA and UK and the rising dietary intakes of linoleic acid have been proposed by Hollander \& Tarnawski (1986). The proposed mechanism for the association between linoleic acid intake and peptic ulcer disease is the rate of synthesis of cytoprotective eicosanoids by the gastric mucosa. Exogenous prostaglandin $\mathrm{E}_{2}\left(\mathrm{PGE}_{2}\right)$ is known to inhibit the induction of experimental ulcers in rats and to accelerate the healing of human peptic ulcers (Miller, 1983). Recently, the ingestion of linoleic acid by healthy human volunteers was reported to increase gastroduodenal synthesis of $\mathrm{PGE}_{2}$ (Grant et al. 1988).

Adipose tissue linoleic acid levels have been shown to reflect accurately long-term dietary intakes of linoleic acid (Van Staveren et al. 1986) and have been used in both epidemiological and case-control studies of diet and coronary heart disease (Fordyce $e t$ al. 1983; Wood et al. 1984). The purpose of the present study was to examine adipose tissue levels of linoleic acid, as an indicator of long-term linoleic acid intake, in peptic ulcer disease. 
Table 1. Age and sex distribution and anthropometric information for the three study groups

(Mean values and standard deviations)

\begin{tabular}{|c|c|c|c|c|c|c|}
\hline Study group... & \multicolumn{2}{|c|}{$\begin{array}{c}\text { Normal healthy } \\
\text { controls }\end{array}$} & \multicolumn{2}{|c|}{$\begin{array}{l}\text { Non-ulcer } \\
\text { dyspepsia }\end{array}$} & \multicolumn{2}{|c|}{$\begin{array}{l}\text { Peptic ulcer } \\
\text { disease }\end{array}$} \\
\hline \multicolumn{7}{|l|}{ No. of } \\
\hline Male smokers & \multicolumn{2}{|c|}{10} & \multicolumn{2}{|c|}{10} & \multicolumn{2}{|c|}{13} \\
\hline Male non-smokers & \multicolumn{2}{|c|}{9} & \multicolumn{2}{|c|}{10} & \multicolumn{2}{|c|}{10} \\
\hline Female smokers & \multicolumn{2}{|c|}{10} & \multicolumn{2}{|c|}{10} & \multicolumn{2}{|c|}{8} \\
\hline \multirow[t]{2}{*}{ Female non-smokers } & \multicolumn{2}{|c|}{11} & \multicolumn{2}{|c|}{10} & \multicolumn{2}{|c|}{6} \\
\hline & Mean & SD & Mean & SD & Mean & SD \\
\hline Age (years) & 33 & 15 & 42 & 16 & 35 & 14 \\
\hline Wt $(\mathrm{kg})$ & 69 & 14 & 65 & 15 & 67 & 12 \\
\hline Height (m) & 1.68 & 0.09 & 1.69 & $0-07$ & 1.67 & 0.11 \\
\hline Body mass index* & $24 \cdot 4$ & $3 \cdot 6$ & $24 \cdot 2$ & $4 \cdot 0$ & $25 \cdot 1$ & $4 \cdot 1$ \\
\hline Percentage body fat & 26.8 & $7 \cdot 5$ & $26 \cdot 9$ & $7 \cdot 8$ & $23 \cdot 6$ & $9 \cdot 6$ \\
\hline Body fat mass (kg) & $18 \cdot 3$ & $6 \cdot 4$ & $17 \cdot 7$ & $7 \cdot 1$ & $15 \cdot 9$ & 7.7 \\
\hline
\end{tabular}

* Weight $(\mathrm{kg}) /(\text { height }(\mathrm{m}))^{2}$

\section{METHODS}

\section{Patients and controls}

Patients were selected following upper gastrointestinal endoscopy at the Health Care Centre of St James's Hospital. Two groups of dyspeptic patients were selected: one with non-ulcer dyspepsia ( $n$ 40) and one with peptic ulcer disease ( $n$ 38). In the main study on adipose tissue linoleic acid, a control group of forty comprised sixteen patients without dyspepsia who were referred for endoscopy (e.g. anaemia, coeliac disease) and twenty-four normal healthy controls recruited from the staff of St James's Hospital. As far as possible, the groups were balanced for smoking habits and sex (Table 1).

In a complementary study, twenty patients with peptic ulcer disease, twenty with nonulcer dyspepsia (both endoscopically evaluated) and twenty outpatient orthopaedic controls were interviewed to establish which foods, if any, aggravated or relieved upper gastrointestinal discomfort. The questions asked were: 'Can you identify any particular foods that cause you discomfort?' and 'Do you find relief from any particular food?'

\section{Dietary and anthropometric information}

Normal patterns of food intake were determined using a $7 \mathrm{~d}$ diet history method and nutrient intakes were calculated using food tables (Paul \& Southgate, 1978) as adapted in the microcomputer program Microdiet (Bassham \& Fletcher, 1984). Particular care was taken during the interview to record accurately the sources of dietary fat. The intake of individual fatty acids was determined by pooling the intakes of fats from separate food items into sixteen categories of fats for which accurate fatty acid information was available (e.g. dairy fat, beef fat, cereal fat, egg fat, etc.). This was necessary because fat values for some common foods were missing from the database used in the nutrient analysis. Anthropometric criteria recorded for each subject included height, weight and triplicate estimates of four skinfold sites (subscapular, suprailiac, biceps and triceps). All skinfold measurements were made by the same investigator and the values were used to compute body fat percentage. Details of smoking habits and previous medical treatments were 
collected during the diet interview. Individuals were classified as non-smokers if they had never smoked tobacco in any form or if they had ceased smoking more than 1 year before the study.

\section{Adipose tissue sampling and analysis}

The method of Beynen \& Katan (1985) was used. Evacuated tubes (Vacutainers; Becton Dickinson, New Jersey) were used to aspirate small quantities of abdominal subcutaneous fat through a 19-gauge needle attached to a Luer-Lock Vacutainer adapter. The method was rapid, painless, convenient and yielded ample tissue for analysis. Samples were stored at $-20^{\circ}$ for subsequent analysis of the methyl esters by gas-liquid chromatography (GLC). Lipids were extracted using chloroform:methanol $(2: 1, \mathrm{v} / \mathrm{v})$, transmethylated using sodium methoxide and analysed for component fatty acids against known standards on a Shimadzu 8A GLC using a $1.6 \mathrm{~m} \times 5 \mathrm{~mm}$ column of $10 \%$ Silar $10 \mathrm{C}$ coated on $80-100$ Chromasorb mesh. The column temperature was run from $100^{\circ}$ to $220^{\circ}$ at $4^{\circ} / \mathrm{min}$ and the temperature of the injector and flame ionisation detector was $200^{\circ}$. The flow rate of the carrier gas $\left(\mathrm{N}_{2}\right)$ was $3 \mathrm{~kg} / \mathrm{cm}^{2}$ and the output values were integrated using a Waters 740 integrator.

\section{Statistical analysis}

Adipose tissue fatty acids and the majority of nutrient intakes are normally distributed (Van Staveren et al. 1986; Black, 1986). Analysis of variance was carried out on the values. Where the resultant $F$ value was significant $(P<0.05)$, mean values for each dyspeptic patient group were compared with controls using the least significant difference test.

\section{RESULTS}

There were no significant differences in nutrient intakes among the groups, with the exception of dietary fibre where both patient groups had lower mean intakes $(P<0 \cdot 05)$ compared with normal healthy controls (Table 2). The level of linoleic acid $(18: 2 n-6)$ in adipose tissue was significantly lower than in normal healthy controls (Table 3 ) in both patient groups, the difference being greater for the patients with peptic ulcer disease $(P<$ $0.001)$ and less for patients with non-ulcer dyspepsia $(P<0.05)$. Three-way analysis of variance failed to demonstrate any effect of sex or smoking or any interaction between sources of variation on either dietary or adipose tissue levels of linoleic acid. The lower levels of linoleic acid in the adipose tissue of the two patient groups were associated with higher, though not significantly higher, levels of oleic acid $(18: 1 n-9)$ and palmitoleic acid $(16: 1 n-7)$. Within the non-ulcer dyspepsia category, no significant difference was found in mean adipose tissue linoleic acid content $(\mathrm{g} / 100 \mathrm{~g})$ among groups of patients with different endoscopic findings; normal endoscopy (13.2 (SD 3.6), $n$ 18), oesophagitis (12.8 (SD 4.3), $n 8$ ) and duodenitis (11.7 (SD 4.4), $n$ 14). Similarly, mean adipose tissue linoleic acid levels $(\mathrm{g} / 100 \mathrm{~g})$ in patients with peptic ulcer disease were equivalent in those with newlydiagnosed ulcers (12.6 (SD 2.8), $n$ 22) and with ulcer relapse (11.6 (SD 2.6), $n$ 16). Analysis of the anthropometric values (Table 1) showed no significant differences among the patient groups in weight, height, body mass index, body fat percentage or body fat mass. Although the total body reserves of linoleic acid (assuming homogeneity of the compositions of all adipose tissue sites) reflected the pattern for adipose tissue linoleate levels (Table 3), there were no significant differences among the groups given the large variation in estimates of body fat reserves.

Table 4 gives the results of the complementary study. Certain foods were clearly associated with the onset and relief of upper gastrointestinal symptoms. Onions, peppers 
Table 2. Mean daily intakes of nutrients $(\mathrm{g} / \mathrm{d})$ and fatty acid composition of dietary fat $(\mathrm{g} / 100 \mathrm{~g})$ in the three study groups

(Mean values and standard deviations)

\begin{tabular}{|c|c|c|c|c|c|c|}
\hline \multirow[t]{2}{*}{ Study group... } & \multicolumn{2}{|c|}{$\begin{array}{l}\text { Normal healthy } \\
\text { controls }\end{array}$} & \multicolumn{2}{|c|}{$\begin{array}{l}\text { Non-ulcer } \\
\text { dyspepsia }\end{array}$} & \multicolumn{2}{|c|}{$\begin{array}{c}\text { Peptic ulcer } \\
\text { disease }\end{array}$} \\
\hline & Mean & SD & Mean & $\mathrm{SD}$ & Mean & $\mathrm{SD}$ \\
\hline Energy $(\mathrm{MJ} / \mathrm{d})$ & $10 \cdot 2$ & $2 \cdot 7$ & $10 \cdot 1$ & $3 \cdot 8$ & $11 \cdot 0$ & 3.7 \\
\hline Protein & 79 & 22 & 75 & 26 & 82 & 25 \\
\hline Carbohydrate & 262 & 87 & 295 & 122 & 320 & 151 \\
\hline Fat & 110 & 35 & 107 & 44 & 115 & 38 \\
\hline Dietary fibre & $20 \cdot 2$ & $11 \cdot 2$ & $15.9 *$ & $6 \cdot 2$ & $15 \cdot 2^{*}$ & $7 \cdot 8$ \\
\hline \multicolumn{7}{|l|}{ Dietary fatty acids $(\mathrm{g} / 100 \mathrm{~g})$} \\
\hline Myristic acid $(14: 0)$ & $7 \cdot 3$ & $3 \cdot 4$ & 8.6 & 3.7 & $7 \cdot 4$ & $3 \cdot 4$ \\
\hline Palmitic acid (16:0) & $25 \cdot 6$ & $9 \cdot 6$ & $24 \cdot 4$ & $10 \cdot 9$ & $25 \cdot 4$ & $9 \cdot 1$ \\
\hline Palmitoleic acid $(16: 1 n-7)$ & $3 \cdot 2$ & $1 \cdot 7$ & $2 \cdot 9$ & $1 \cdot 2$ & $3 \cdot 0$ & 0.9 \\
\hline Stearic acid $(18: 0)$ & $11 \cdot 2$ & $3 \cdot 2$ & $11 \cdot 4$ & $5 \cdot 3$ & 11.9 & 4.5 \\
\hline Oleic acid $(18: \ln n-9)$ & $30 \cdot 3$ & $10 \cdot 0$ & $28 \cdot 3$ & $11 \cdot 3$ & $28 \cdot 2$ & $9 \cdot 0$ \\
\hline Linoleic acid $(18: 2 n-6)$ & $7 \cdot 7$ & $6 \cdot 4$ & $5 \cdot 5$ & $4 \cdot 1$ & $5 \cdot 9$ & $4 \cdot 5$ \\
\hline
\end{tabular}

* Mean value was significantly different from that for normal healthy controls $(P<0.05)$.

Table 3. The composition of adipose tissue fatty acids $(\mathrm{g} / 100 \mathrm{~g})$ in the three study groups (Mean values and standard deviations)

\begin{tabular}{|c|c|c|c|c|c|c|}
\hline \multirow[t]{2}{*}{ Study group... } & \multicolumn{2}{|c|}{$\begin{array}{c}\text { Normal healthy } \\
\text { controls }\end{array}$} & \multicolumn{2}{|c|}{$\begin{array}{l}\text { Non-ulcer } \\
\text { dyspepsia }\end{array}$} & \multicolumn{2}{|c|}{$\begin{array}{l}\text { Peptic ulcer } \\
\text { disease }\end{array}$} \\
\hline & Mean & SD & Mean & So & Mean & SD \\
\hline Myristic acid (14:0) & $5 \cdot 7$ & $2 \cdot 7$ & $5 \cdot 2$ & 1.7 & $6 \cdot 3$ & $4 \cdot 5$ \\
\hline Palmic acid $(16: 0)$ & $20 \cdot 6$ & $2 \cdot 4$ & $21 \cdot 7$ & $2 \cdot 5$ & $19 \cdot 6$ & $2 \cdot 1$ \\
\hline Stearic acid $(18: 0)$ & $3 \cdot 1$ & 0.6 & $3 \cdot 1$ & 0.7 & $3 \cdot 3$ & 0.7 \\
\hline Palmitoleic acid $(16: 1 n-7)$ & $9 \cdot 3$ & $2 \cdot 8$ & $9 \cdot 7$ & $2 \cdot 1$ & $9 \cdot 7$ & 1.9 \\
\hline Oleic acid $(18: \ln -9)$ & $45 \cdot 4$ & 3.6 & $46 \cdot 7$ & $4 \cdot 0$ & $46 \cdot 1$ & $4 \cdot 1$ \\
\hline Linoleic acid $(18: 2 n-6)$ & 15.0 & $4 \cdot 1$ & $12 \cdot 8^{*}$ & $3 \cdot 5$ & $11 \cdot 7^{* * *}$ & 2.7 \\
\hline \multirow[t]{2}{*}{$\alpha$-Linolenic acid $(18: 3 n-3)$} & $2 \cdot 3$ & 0.6 & $2 \cdot 2$ & $0 \cdot 9$ & $2 \cdot 4$ & $0 \cdot 8$ \\
\hline & \multicolumn{6}{|c|}{ body reserves $(\mathrm{kg})$} \\
\hline Linoleic acid $(18: 2 n-6)$ & $2 \cdot 78$ & $1 \cdot 34$ & $2 \cdot 3$ & $1 \cdot 1$ & 1.93 & 1.04 \\
\hline
\end{tabular}

Mean value was significantly different from that for normal healthy controls: ${ }^{*} P<0.05$, ${ }^{* * *} P<0 \cdot 001$.

and fatty or fried foods were found to irritate both patient groups. More of the ulcer group found alcohol an irritant, while citrus fruits were cited more frequently by the non-ulcer dyspeptics as a cause of discomfort. Both groups found milk alleviated their symptoms.

\section{DISCUSSION}

Values for adipose tissue linoleate reported in the literature indicate a marked inter- and intra-regional variation. Much of the intra-regional variation is due to different rates of change of intake of linoleic acid over time. Handleman et al. (1988) have shown how, over 
Table 4. The aggravation and alleviation of upper gastrointestinal symptoms by foods in patients with duodenal ulcer, non-ulcer dyspepsia and non-dyspeptic orthopaedic control patients

\begin{tabular}{lccc}
\hline Study group... & $\begin{array}{c}\text { Duodenal } \\
\text { ulcer }\end{array}$ & $\begin{array}{c}\text { Non-ulcer } \\
\text { dyspepsia }\end{array}$ & $\begin{array}{c}\text { Orthopaedic } \\
\text { controls }\end{array}$ \\
Males & 16 & 12 & 14 \\
Females & 4 & 8 & 6 \\
Total no. & 20 & 20 & 20 \\
Symptoms associated & 13 & 14 & 2 \\
$\quad$ with foods & & & \\
Foods causing discomfort & 11 & 9 & 2 \\
$\quad$ Onions/peppers & 10 & 10 & 0 \\
$\quad$ Fatty/fried foods & 9 & 4 & 0 \\
$\quad$ Alcohol & 5 & 8 & 0 \\
$\quad$ Citrus fruits & 4 & 7 & 0 \\
$\quad$ Spices & 3 & 2 & 0 \\
$\quad$ Rich cakes & 3 & 1 & 0 \\
$\quad$ Fizzy drinks & 2 & 1 & 0 \\
$\quad$ Cabbage & & & \\
Foods giving relief & 12 & 10 & 0 \\
$\quad$ Milk & 4 & 2 & 0 \\
$\quad$ Bread & & & \\
\hline
\end{tabular}

the last 20 years, the intake of linoleic acid in the USA, as indicated by adipose tissue concentrations, has doubled from 9 to $18 \mathrm{~g} / 100 \mathrm{~g}$. This trend has been previously described by Katan \& Beynen (1981) who also showed that linoleate intakes in the UK remained constant during this period. The values reported in the present study are higher than those recently reported for Scottish adults (Wood et al. 1984) and are more comparable to concentrations found in The Netherlands (Plakke et al. 1983; Van Staveren et al. 1986).

The extent of the difference in adipose tissue linoleate between patients and controls observed in our study $(15.0 \mathrm{v} .11 .7 \%)$ was somewhat unexpected, and prompted further investigation. The first task was to determine whether dyspeptic symptoms per se are influenced by certain foods such that dyspeptic patients would modify their eating habits. The results clearly show that, in contrast to orthopaedic patients, patients with dyspepsia with or without ulcers identify certain foods that aggravate their symptoms and others that relieve them. Accordingly, some of the differences in dietary habits among the groups may be due to modified food selection, secondary to symptoms. The extent of adverse reactions to food is quite widespread at about $33 \%$ of the population (Bender \& Matthews, 1981). The majority of these adverse reactions involve the gut: nausea $30 \%$, vomiting $17 \%$, indigestion $16 \%$ and diarrhoea $7 \%$. To date, no information is available concerning the types of foods preferred or avoided in the presence of specific gastrointestinal symptoms.

The incidence of peptic ulcer disease decreases with increasing socioeconomic class (SEC) (Department of Health and Social Security, 1980). Adipose tissue levels of linoleate decrease with decreasing SEC (Fulton et al. 1988). The design of our present study did not allow testing concentrations for this source of variation, leaving the possibility that the lower linoleate in the adipose tissue of patients was a result of sampling bias (i.e. patients mainly SEC 5 and 6, controls largely SEC 1 and 2). As the available information did not facilitate satisfactory SEC grouping of patients, the local health authority categories of entitlement to medical care were used as an alternative. 
Table 5. Adipose tissue linoleic acid levels in patients with peptic ulcer disease, patients with non-ulcer dyspepsia and normal healthy controls classified according to entitlement to free medical care

(Mean values and standard deviations)

\begin{tabular}{|c|c|c|c|c|c|c|}
\hline \multirow[t]{3}{*}{$\begin{array}{l}\text { Category... } \\
\text { Entitlement to free medical care... }\end{array}$} & \multicolumn{2}{|c|}{$\begin{array}{c}1 \\
\text { Full }\end{array}$} & \multicolumn{2}{|c|}{$\stackrel{2}{\text { Partial }}$} & \multicolumn{2}{|c|}{$\begin{array}{c}3 \\
\text { None }\end{array}$} \\
\hline & \multicolumn{6}{|c|}{ GMS entitlement distribution } \\
\hline & $n$ & $\%$ & $n$ & $\%$ & $n$ & $\%$ \\
\hline Peptic ulcer disease & 24 & 63 & 11 & 29 & 3 & 8 \\
\hline Non-ulcer dyspepsia & 18 & 45 & 22 & 55 & 0 & --- \\
\hline \multirow[t]{3}{*}{ Normal healthy controls } & 9 & 22 & 23 & 56 & 8 & 22 \\
\hline & \multicolumn{6}{|c|}{ Adipose tissue linoleic acid $(\mathrm{g} / 100 \mathrm{~g})$} \\
\hline & Mean & SD & Mean & SD & Mean & SD \\
\hline Peptic ulcer disease & $11 \cdot 8$ & $2 \cdot 7$ & $12 \cdot 5$ & $2 \cdot 6$ & $14 \cdot 0$ & $3 \cdot 1$ \\
\hline Non-ulcer dyspepsia & $12 \cdot 7$ & $3 \cdot 5$ & $13 \cdot 4$ & $3 \cdot 5$ & - & 一. \\
\hline Normal healthy controls & $13 \cdot 5$ & $3 \cdot 1$ & $14 \cdot 5$ & $3 \cdot 3$ & $18 \cdot 6$ & $5 \cdot 2$ \\
\hline
\end{tabular}

GMS, general medical service.

The results are shown in Table 5. Category 1 patients, entitled to full free medical care, fall principally into SEC 5 and 6 . Those in category 3 , with no entitlement to free medical care, are mainly from SEC 1 and 2. These categories are therefore crude indices of SEC. Nonetheless, the positive relationship between SEC and peptic ulcer disease is evident, as is the decline in adipose tissue linoleic acid with decreasing SEC. When the values for categories 1 and 2 were subjected to two-way analysis of variance (the numbers in category 3 were too small for inclusion), both disease status and SEC were found to influence significantly the concentration of adipose tissue linoleate $(P<0.05$; error mean square, $9 \cdot 7$; 103 error d.f.). Thus, the concentrations of adipose tissue linoleate fall from $18.6 \%$ in the higher SEC controls to $13.5 \%$ in the lower SEC controls. The respective values for patients with peptic ulcer disease are 14.0 and $11.8 \%$.

Whilst eicosanoids and essential fatty acids clearly play a protective role in gastric cytoprotection (Miller, 1983; Grant et al. 1988), considerable caution should be exercised in attempting to establish a causal relationship between the decline in incidence of peptic ulcer disease and an increase in essential fatty acid intakes, as has been proposed (Hollander \& Tarnawski, 1986). Many studies have shown that increasing intakes of dietary linoleic acid do not increase the concentration of the eicosanoid precursor, arachidonic acid, in membrane phospholipids (Dupont et al. 1980; Elson et al. 1982; Vas Dias et al. 1982; Blaton et al. 1984; Charnock et al. 1985; Lasserel et al. 1985; Huang et al. 1987; Bolton-Smith et al. 1988). There are also conflicting reports on the effect of dietary linoleic acid supplements on eicosanoid synthesis in man. Moderate levels of supplementation with linoleate do not increase systemic production of the E prostaglandins, although high, pharmacological doses appear to enhance both local (Grant et al. 1988) and systemic (Adam et al. 1982) $\mathrm{PGE}_{2}$ production. An increase in eicosanoid synthesis due to linoleate supplementation is, however, possible without an increase in phospholipid arachidonate. Crawford (1983) has proposed that phosphatidyl inositol, with a high concentration of arachidonate and a rapid rate of turnover, could provide a phospholipid 
pool with a high flux of arachidonate in response to increased linoleate intake. In that way, a recent high intake of linoleate could stimulate an increased rate of eicosanoid synthesis without an accumulation of arachidonate in cell membrane phospholipids.

In conclusion, adipose tissue levels of linoleic acid decline with increasing severity of dyspepsia and this effect is independent of SEC. Our findings do not allow any judgement to be made regarding the possibility of a causal relationship between essential fatty acid intake and peptic ulcer disease. Some evidence from the present study suggests that upper gastrointestinal symptoms per se may influence food selection, with the possible consequence of altered nutrient intake. A final possibility is that a chronic inflammatory condition such as gastroduodenitis or peptic ulcer disease, may result in a chronically increased demand for eicosanoid synthesis of sufficient magnitude gradually to reduce adipose tissue linoleic acid reserves.

\section{REFERENCES}

Adam, O., Wolfram, C. \& Zöllner, N. (1982). Prostaglandin formation in man during intakes of different amounts of linoleic acid in formula diets. Annals of Nutrition and Metabolism 26, 315-323.

Bassham, S. \& Fletcher, L. R. (1984). Calculation of nutrient intake by microcomputer. Proceedings of the Nutrition Society 44, 36A.

Bender, A. E. \& Matthews, D. R. (1981). Adverse reactions to foods. British Journal of Nutrition 46, $403-408$.

Beynen, A. C. \& Katan, M. B. (1985). Rapid sampling and long term storage of subcutancous adipose tissue biopsies for determination of fatty acid composition. American Journal of Clinical Nutrition 42, 317-322.

Black, A. E. (1986). The use of recommended daily allowances to assess dietary adequacy. Proceedings of the Nutrition Society 45, 369-381.

Blaton, V., DeBuyzere, M., Declerg, B., Pracetyo, A., Vanderkeller, A., Delanghe, J. \& Spincemaille, J. (1984). Effect of polyunsaturated isocaloric fat diets on plasma lipids and fatty acids. Atherosclerosis $\mathbf{5 3}, 9-29$.

Bolton-Smith, C., Gibney, M. J., Gallagher, P. J., Jewell, R. \& Hillier, K. (1988). Effect of polyunsaturated fatty acids of the $n-3$ and $n-6$ series on lipid composition and eicosanoid synthesis of platelets and aorta and on immunological induction of atheroselerosis in rabbits. Atherosclerosis 72, 29-35.

Charnock, J. S., McIntosh, G. H., Abervardena, M. Y.\& Russel, G. R. (1985). Changes in fatty acid composition of the cardiac phospholipids of the cotton-eared Marmoset (Callithrix jacchus) after feeding different lipid supplements. Annals of Nutrition and Metabolism 29, 83-94.

Crawford, M. A. (1983). Background to essential fatty acids and their prostanoid derivatives. British Medical Bulletin 39, 210-213.

Department of Health and Social Security (1980). Inequalities in Health: Report of a Research Working Group (Black Report). London: DHSS.

Dupont, J., Mathias, M. M. \& Connally, P. T. (1980). The effects of dietary essential fatty acid concentration upon prostanoid synthesis in rats. Journal of Nutrition 110, 1695-1702.

Elson, C. E., Benevenga, N. J., Canty, D. J., Gummer, R. H., Lalich, J. J., Porter, J. W. \& Johnston, A. E. (1982). The infiuence of dietary unsaturated cis-and trans-saturated fatty acids on tissue lipids of swine. Atherosclerosis 40. $115-137$.

Fordyce, M. K., Christanis, A., Kafotos, A., Duncan, R. \& Cassady, J. (1983). Adipose tissue fatty acid composition of adolescents in a US - Greece cross-cultural study of coronary heart disease risk factors. Journal of Chronic Disease 36, 481-486.

Fulton, M., Thomson, M., Elton, R. A., Crown, S., Wood, D. A. \& Oliver, M. F. (1988). Cigarette smoking, social class and nutrient intake: relevance to coronary heart disease. European Journal of Clinical Nutrition $\mathbf{4 2}$, 797-803.

Grant, H. W., Palmer, K. R., Kelly, R. W., Wilson, N. H. \& Misiervicz, J. J. (1988). Dietary linoleic acid, gastric acid and prostaglandin secretion. Gastroenterology $\mathbf{9 4 , 9 5 5 - 9 5 9 .}$

Handleman, G. J., Epstein, W. L., Lawrence, J. M., van Kuijk, F. J. G. M. \& Dratz, E. A. (1988). Biopsy method for human adipose with vitamin E and lipid measurements. Lipids 23, 598-604.

Hollander, D \& Tarnawski, A. (1986). Dietary cisential fatty acids and the decline in peptic ulcer disease - a hypothesis. Gut 27, 239-242.

Hollander, D., Tarnawski, A., Ivery, K. J., Van de Freery, A., Zipser, R. D., McKenzie, W. A. \& McFarland, W. D. (1982). Arachidonic acid protection of rat gastric mucosa against ethanol injury. Journal of Laboratory and Clinical Medicine 100, 296-308.

Huang, Y. S., Drummond, R. \& Horribim, D. F. (1987). Protective effect of $\gamma$-linolenic acid on aspirin-induced gastric haemorrhage in rats. Digestion $36,36-41$.

Katan, M. B. \& Beynen, A. C. (1981). Linoleic acid consumption and coronary heart disease in USA and UK. Lancet ii, 371 . 
Lasserel, M., Mendy, F., Spielman, D. \& Jacotot, B. (1985). Effects of different dietary intakes of essential fatty acids on $\mathrm{C} 20: 3 \omega 6$ and $\mathrm{C} 20: 4 \omega 6$ levels in human adults. Lipids 20, 227-233.

Miller, T. A. (1983). Protective effects of prostaglandins against gastric mucosal damage : current knowledge and proposed mechanisms. American Journal of Physiology 245, G601-G623.

Paul, A. A. \& Southgate, D. A. T. (1978). McCance \& Widdowson's The Composition of Foods, 4th ed. London: H. M. Stationery Office.

Plakke, T., Berkel, J., Beynen, A. C., Hermus, R. T. J. \& Katan, M. B. (1983). Relationship between the fatty acid composition of the diet and that of subcutaneous adipose tissue in individual human subjects. Human Nutrition: Applied Nutrition 37 A, 365-372.

Tarnawski, A., Hollander, D. \& Stachura, J. (1985). Is linoleic acid (dietary essential fatty acid) cytoprotective for the gastric mucosa? Gastroenterology 88, 1610.

Van Staveren, W. A., Deurenberg, P., Katan, M. B., Burema, J., de Groot, L. \& Hoffmans, M. D. (1986). Validity of the fatty acid composition of subcutaneous fat tissue microbiopsies as an estimate of the long-term average fatty acid composition of the diet of separate individuals. American Journal of Epidemiology 123, $455-463$.

Vas Dias, F. W., Gibney, M. J. \& Taylor, T. G. (1982). The effect of polyunsaturated fatty acids of the $n-3$ and $n-6$ series on platelet aggregation and platelet and aorta fatty acid composition in rabbits. Atherosclerosis $\mathbf{4 3}$, 245-257.

Wood, D. A., Butler, S. \& Reimersma, R. A. (1984). Adipose tissue and platelet fatty acids and coronary heart disease in Scottish men. Lancet ii, 117-121. 